\section{JIBM}

Journal of International Business and Management (JIBM) Journal Homepage: https://rpajournals.com/jibm

\title{
A Critical Analysis of Internal and External Environment: Case Study of Apple Inc.
}

\author{
Choo Eern Yie" \\ Choo Eern Zhi ${ }^{2}$ \\ Nicole Tham Seow Ping \\ School of Management \& Marketing ${ }^{123}$ \\ Taylor's University Lakeside Campus, Malaysia' ${ }^{123}$
}

\begin{abstract}
Apple Inc. is a famous information technology firm in the global market. The organization has a wide range of products which consists of MacBook, iPhones, Apple $\mathrm{TV}$, iPad and Apple watch. In this era of globalization with technologies, Apple's users seek for unique performance products that are aesthetically pleasing as well as emphasize good product qualities. In 1976, Apple was established by Steve Jobs and his partners to develop modern technology products. In order to assess Apple's strategic capabilities, Osterwalder's Business Model Canvas is applied in this case study. There is several competitive analysis tools are written in this article including Internal Factor and External Factor Evaluation matrix, SWOT and SPACE Matrix, Boston Consulting Group (BCG) analysis as well as Internal-external (IE) analysis to evaluate Apple's competitive intelligence. Throughout the report, every component in the evaluation model reflects the direction of how Apple overcomes the hurdles and how Apple could benefit by expanding their business in the international market. Lastly, Sun Zi's Art of War is also being studied and included into business strategies of Apple.
\end{abstract}

Keywords: Apple, Osterwalder, Factor Evaluation Matrix, SWOT, SPACE Matrix, Internal-external Analysis, Sun Zi's Art of War

*Corresponding author: Choo Eern Yie; Email: yie793@gmail.com DOI: https://doi.org/10.37227/JIBM-2021-08-149

\begin{abstract}
Introduction
Apple Inc. is recognized as the top few companies in the IT sector, which provides online services and products for the consumers. They are also the world's largest publicly traded institution. For instance, computer software, computer peripherals, personal laptops etc. The computer hardware is known as iPhone, iPad, MacBook and iPod. Whereas software includes macOS, iOS, iPadOS and etc. Apple Inc. was founded by Steve Jobs, Ronald Wayne and Steve Wozniak. At the same time, Mike Markkula entered into Apple Inc. and assisted them in the business expansion. Moreover, Bill Gates invested \$150 million and partnered with Jobs into a long-term battle by developing Internet Explorer on all Apple computers (Ahmer, 2019). This has also led Apple Inc. to bring in more interesting and creative contents into the products and to educate their target market (Aljafari, 2016). According to CNN Business (2006), the institutional investors retain the majority of the ownership, $59.45 \%$, which makes the company might be facing inconsistent movement of stock price if the
\end{abstract}


organization implemented barriers on the open market. However, the insider ownership of Apple Inc. is able to hold a smaller percentage than institutional investors. Higher levels of insider ownerships are required to assist in management to implement high-return projects for the growth of Apple Inc. (Wall, 2018). Since Apple Inc. is offering innovation, creativity and premium technologies to their users, they have also determined their target market. Most of the users are highly educated millennials, have a career as well as an active social life. Apple Inc. mostly targets students, professionals, executives and managers that have a potential income background (Johnson et al, 2012).

Apple's Mission and Vision statements are the foundation of the company's achievement to be the best company in the world. They have changed their vision and mission statement over time in order to fit into the changing market conditions. It is fundamental for an organization to set a vision that organization would like to accomplish in the long term goal. A clear vision statement helps an organization to define its goals by allowing the company to realize what they want to become in the industry as well as providing an establishment to develop inclusive mission statements. The vision statement of Apple is "man is the creator of change in this world. As such he should be above systems and structures, and not subordinate to them" (Blodget, 2013). Apple carries their vision by developing technological products for clients and organisations. They attempt to make their clients master the product that they have purchased. Apple abides by their vision statement and ensuring its employees understand and achieve it. They were also required to have shared goals in order to have smooth interaction with customers. Moreover, Apple has set some business goals to be pushed ahead by applying business strategies to achieve these goals. In this, Apple ensures they are having proper marketing and operations structure. For instance, they are utilizing their social media channels to market and build long lasting relationships with their clients. In 2016, Apple created a Support Twitter account to assist customers deal with their issues by providing accurate tips and feedback (Mastroianni, 2016). This has helped Apple to maintain its customer loyalty and be able to set their future goals and values.

In addition, the mission statement is used by an organization to explain their purpose for being, which indicates how the company is different from other competitors. It helps to support the vision statement and serves to lead direction to their employees, vendors and stakeholder. The mission statement of Apple is "to bring the best personal computing products to consumers around the world through its innovative hardware, software and Internet offerings." (Apple.com, 2000). This shows what the company does and will accomplish, which is by providing the "best' in inventing and designing electronic devices in the world. As they have manufactured high quality products such as iPhone, iPad and MacBook, consumers will have high expectations on their quality and performances. So, their mission is a complementary assurance to their customers of providing the best products for them. Likewise, Apple also keeps inventing and maintaining their high quality products which therefore has set a higher industry standard to their competitors. Their mission has clearly shown that adequate improving and upgrading are required for a business to achieve their objectives. Apple pursued its vision and mission statement to achieve its plan. The vision and mission of Apple helps to bring direction to the organizational strategy by providing important components of a strategy: objectives and goals. By finding the objectives and goals, Apple is able to create a step-by-step strategy that helps the company to achieve its mission and statement. Furthermore, vision and mission statements also provide a goal for employees to achieve and improve their efficiency of work.

The aim of this paper is designed to provide readers a holistic approach to contemporary issues and practices in business. An analysis of internal environment looks into factors within business such as their strength and weaknesses. However, the external analysis is concentrate at wider business environment that could bring impact to business. The important of the internal and external environment of the case study is crucial and should be highly considered by any company that wish to be profitable in this highly competitive international business arena. Therefore, the objective could be accomplished through critical analysis of environment analysis for Apple by several tool such as Internal Factor and External Factor Evaluation matrix, SWOT and SPACE Matrix, Boston 
Consulting Group (BCG) analysis as well as Internal-external (IE) analysis. In this paper, readers are also able to learn and apply the strategies of The Art of War in the Modern business.

\section{Research Methodology}

The purpose of the paper is to study the strategic capabilities of Apple Inc. With a view to conduct the research for the paper, all the data was collected from secondary sources. This case study report heavily banked on secondary data and these data were collected using several published sources on Apple Inc. In order to achieve the objectives, internal and external environment of Apple were analyses as well as studied the Sun Zi's Art of War which relevant to the Apple's business strategies, with the help of various competitive analysis tools.

\section{Osterwalder's Business Model Canvas for Apple Inc.}

Business model canvas is a strategic management tool to determine and communicate a new business model (Sheda, 2016). This model is able to assist Apple in competing in the competitive edge to have a profitable business by not just providing product innovation but also business planning.

\section{Key Partners}

Their key partners include App store developers, manufacturers, television, music and movie industry. Apple's app store developers have created a platform for iOS users where they are able to download any mobile applications into their iPhone, MacBook and iPad. Moreover, Apple provides entertainment to their end users by collaborating with music industries. For instance, iTunes has successfully transformed the music industry as previously, it was a platform for the music companies to sell their MP3s, yet Apple expanded iTunes and made some profitable investments (Montgomerie and Roscoe, 2013). Due to this, they have become the market leader of music retailers in the US. Similarly, Apple has also invested in the movie industry via their Apple TV, which provides users to enjoy high quality shows and movies. They have collaborated with Hollywood producers to have their own movie or shows on Apple TV (Castro, 2020).

\section{Key Activities}

Apple is involved in various activities including design, quality control, manufacturing and software development. There's key activities performed by the company that have led to delivering value propositions for the company. For instance, Apple has provided a lot of investment in their marketing of its products. Their marketing skills of Apple are special and successful to differentiate Apple from other brands. Apart from marketing, Apple also provides a lot of investment in their research and development. Apple keeps on creating new products to upgrade their products through innovation. Apple has always focused on design products which meet the needs and demands of its consumers.

\section{Key Resources}

Apple has expanded globally to become the most profitable businesses, in which they are serving more than millions of customers and retail outlets located around different parts of the world. In human capital and physical resources wise, the company has employed 137,000 full-time employees and retained an amount of 510 retail stores in more than 20 countries this year (Farfan, 2019). Intellectual resources that include trademarks and copyrights takes time to be developed, and will provide unique advantages for Apple. The company must make use of its resources to gain new clients, improve the business as well as generate revenues (Apple.com, 2020).

\section{Value Propositions}

Their key value propositions include performance, status/brand, convenience/usability and design. The first value provided by Apple to customers is convenience. All models introduced by Apple including iPhone, IPod and iMac are user friendly. The second value provided by Apple is to improve the products through expanding the storage capacity and increase the speed in their latest models. The third value is inventing new designs that are simpler and special than competitors. The fourth 
value is reducing the risk of product. Apple provides warranties and guarantees toward their products in order to protect consumers from risk.

\section{Revenue Stream}

The main revenue of Apple comes from the sale of IPhone. According to Apple's financial statement (2020), the sale of IPhone in the 3rd Quarter of 2020 is $\$ 26,418$. The second source of revenue is from Mac which is $\$ 7,079$. The remaining revenue comes from the sales of Apple's products like iPad, Earpods, Apple TV and Apple's accessories. Furthermore, Apple also provides services like licensing from other services, Apple Pay and digital contents and services offered by Apple. Apple gains revenue from their service. Based on the same financial report in the Quarter 3 of 2020, Apple receives $\$ 13,156$ from the sale of service.

\section{Customer Segment}

The target customer segment for Apple will be working adults, college students and teenagers as they are the group of people who are familiarized with social media platforms such as Facebook, YouTube and etc (Appel, et. al, 2019). MacBook are more targeted towards college and university students as they utilize it by recording notes and their assignments. The targeted customer segment favors MacBook over other brands due to its high resolution and light weight. Moreover, for working adults, they are more easily able to receive documents and smooth communication with their subordinates and customers. Similarly, iPhones are favored by parents for the learning purposes of their children, accurate map direction, making phone calls etc.

\section{Distribution Channels}

There are several distribution channels for Apple to distribute their products globally, which comprises retail outlets and online stores. Besides the amount of retail outlets that have been published, there are thousands of online stores in different countries on a global scale to provide hardware and software to their customers (Montgomerie and Roscoe, 2013). In this case, targeted customers are able to acquire Apple products on online stores, such as the official website "Apple.com" and retailer stores. Online and offline distribution channels will assist the company to achieve desired sales revenue and be able to fulfil the needs of customers instantly (AllianceExperts.com, 2020).

\section{Cost Structure}

The market price of all Apple products are determined by the company. The company is forced to adjust their prices due to lack of parts and high competition in the industry. Over the years, the cost structure of Apple has been affected by price fluctuation due to external forces including high competition from Huawei and Samsung. The cost structure of Apple is different based on the products that the company offers. The price of key products including IPhone and Mac is charged by their value proposition. Apple also carries out mass production to take benefits of economies of scale. The benefits of mass production is Apple able to charge acceptable prices for their products.

\section{Apple Inc.'s Strategy-Formulation Analytical Framework Internal Factor Evaluation Matrix (IFE)}

IFE tool is a strategy-formulation matrix that evaluates and summarizes the weakness and strength of Apple's business functional area (David, 2011). Apple is considered the first valuable brand in the world. According to Forbes, the brand value of Apple in 2020 is US\$241,200 billion (Swant, 2020). It has a good reputation in inventing the best electronic devices and offering excellent customer experiences. Apple achieves strong branding and reputation with large advertising and good marketing skills. All of these factors have made Apple to build the best brand in the world. In addition, it also has the potential to invent and design their own electronic products, service, and operating system as well as end-user programs. This has allowed Apple to provide innovative, special and easy-to-use products that would be able to solve customer problems in their daily life activities. 
This has created a strong competitive advantage that no competitors are unable to defeat. Next, Apple has a large customer loyalty base. For instance, they offer innovative and convenient portable devices, such as iPad, which attract customers' attention. They are willing to purchase iPad and enjoy this product as it is well-functioned. Apple's products are authentic, trustable and appealing which is the reason customers continue to be loyal with Apple even though there are a variety of selections in the market (Haselton, 2017).

Apple Inc. is using a premium price strategy in their products, therefore their products are being considered as luxury products (Nielson, 2020). While one of the weaknesses of Apple is they are having too pricey laptops compared to their competitors. The price of their products is always higher than those standard brands in the market such as Samsung and Huawei. For instance, a standard laptop can cost RM1000 - RM2899, while the price of a MacBook starting from RM5,599, which Apple have set a standard of price ceiling in this industry whereby their competitors are unable to cross the price that Apple has set (Shanklin, 2017). Their price and quality has limited their buyers in the middle or upper class level of students or executives. As Apple is more focusing on the highend group, their products do not cater on the global scale where majority buyers are from lower class. This has led to a limitation on their business model. Moreover, due to this premium pricing strategy, Apple only depends on the sales from high-end segment when lower class segment consumers are not able to purchase their products easily. This is an obvious weakness for Apple as there is just a minority percentage of high-end segments on the global scale (Aljafari, 2016).

Similarly, a huge issue that Apple is facing is labour issues occurred in its supplier - Foxconn, a company that assembles products of Apple. There are several cases that have been discovered by the public where unethical business practices were being conducted in the supply chain. Cases such as employees committed suicide over working conditions at Foxconn (Heffernan, 2013). In addition, child labour were not an issue that they are going to pay attention to (Guo et al, 2012). They are using child labour as they do not need to pay high amount of salary compared to an adult worker to save costs of the company. However, due to their worse working conditions, it has created a negative brand image to the public.

\section{External Factor Evaluation Matrix (EFE)}

EFE matrix allows strategists to evaluate and summarize the threats and opportunities in Apple's business functional area (David, 2011). From the analysis, there is an opportunity for Apple to expand its product line. Although Apple's current products line is a huge success for the company. In order to enhance the business's growth in the global market, Apple should continue in creating new innovative product lines, like their successful wireless Bluetooth earphone, Airpod. According to Apple's press release (2020), Apple's product is currently available in 155 countries. In 2013, Apple had made an announcement that the company will expand its service to 20 more countries, eight of them in Africa and two of them in Asia, two of them in the Middle East and many more (Nellis, 2020). Nevertheless, expanding internationally also helps to increase the growth of Apple's business as the company could capture a large segment of potential customers in targeted markets to experience the Apple's products. The new target audience will help Apple to build its brand recognition worldwide. Next, Apple can present a stronger presence online than any of its competitors (Moorman, 2012). Online presence helps to build Apple's reputation and provides visibility to Apple's products or services. Thus, potential customers are able to reach Apple easily through this contact information online. Apple could also provide business contact information in their social media platform and official website. This has shown that Apple has major opportunities for future growth of business despite there is aggressive competition.

On the other hand, there are some of the threats that would cause an effect on Apple such as competition with Spotify. Apple do have their own iTunes, however users need to purchase song by song with an amount of money. In other words, the situation is totally different with Spotify, in order for users to listen and download music for free, Spotify's users only need to pay RM14.90 every month to be a premium member and enjoy free music (Apple.com, 2019). The price for music in iTunes is RM3.90 per song, which is not favorable by most of the users in terms of price sensitivity. 
Secondly, there is an intense competition between Apple and their competitors. Apple faced a threat when the company only created a standard product design for every model. Therefore, Apple needs to contend with Samsung and Huawei products in the form of aesthetics on smartphones. Moreover, Apple has not built any new innovative products to fulfil the expectations of their target customers (Manjoo, 2016). Hence, some of their customers have switched to their competitors brand. In this case, Apple needs to come out with a new innovative design or product that would remain with the existing customers as well as attract a new group of customer segments in order to stay competitive.

\section{SWOT Matrix}

The matrix of SWOT is a tool for business to develop four major types of strategies. The tool brought advantages such as helping build over business strengths, and also utilizing the best of available opportunities while minimizing the threats together (Phadermrod, Crowder and Wills, 2019). To become the top leading organizations in the IT industry, Apple has countless strengths that help company fast-growing in the marketplace. These strengths not only help Apple to penetrating into new market but also protect the market share. Firstly, using strength to capitalize most of the opportunities. Apple should partner with other brands to produce compatible products (Khan, et. al, 2015). For example, Apple can develop mutually beneficial relationships with international large companies such as Huawei. This will help Apple to hack into other brands' customer base in the China market. However, weaknesses are the areas where Apple can improve using this matrix and build on its competitive advantage as well as strategic positioning. Secondly, for this strategy, the company could overcome weaknesses to capitalize on opportunities. Apple should create a larger range of products and enter into new areas of product in order to serve a new segment of customers (David, et. al, 2017). For instance, Apple can sell older versions of smartphones in a cheaper price range to less developed countries.

This could help Apple to attract other segment middle class customers to reduce its inventory. However, for external strategic forces, using strengths to avoid threats can be one of the strategies for Apple to apply. Apple faced issues such as a China's rise level pay of $\$ 15$ an hour (Valentin, 2001). The treat could lead a serious pressure on Apple's profitability. Shortage of suppliers also pose a threat to Apple. Hence, Apple should control the manufacturing costs by focusing on the relationships with suppliers. With great relationships, the company could establish manufacturing plants in countries with lower labor costs. Lastly, another strategy can be applied is reducing weaknesses to avoid its threats. Apple's marketing products left much to be desired. Although there is success in product sales, eventually the unique selling proposition is unclearly defined which may lead to attack from rivals (Wonglimpiyarat, 2012). For instance, Apple should broaden its range of products and rising competition by promoting new Apple software that is more stable than other brands.

\section{Strategic Position and Action Evaluation (SPACE) Matrix}

Space matrix is a management tool which is broadly utilize by firms to analyze what type of strategy they should undertake to stay competitive in the market and compete with competitors. Y-axis represents FS - Financial strength and ES - Environmental stability, while the $\mathrm{X}$-axis represents CA - Competitive advantage and IS - Industry strength. This will show the company where they are being positioned in the market: conservative, aggressive, competitive and defensive. Financial Strength is one of the internal strategic positions. There are many factors that would affect their financial strength. Firstly, growth of revenue. The revenue of Apple at the third quarter of 2020 is $\$ 59.685 \mathrm{~b}$, a slight increase of $10.92 \%$ from the previous year (Csimarket.com, 2020). Secondly, Apple had a net sales of $\$ 42.925 \mathrm{~m}$ in 2009 and their net sales increased to $\$ 65.225 \mathrm{~m}$ in 2010 . Thirdly, earning per share. If there is an increase in earnings per share, the profit increases as well. In this case, Apple has an increase rate of 18\% in EPS in the 3rd Quarter of 2020 (Forexfactory.co, 2020).

In addition, stability position is one of the external strategic positions. First factor that can influence the stability position is the pressure of rivals. Apple faces high pressure from strong rivals such as Samsung, Huawei and Oppo. The second factor that influences stability position is price 
sensitivity of competitors. The price of Apple's product is higher than its competitors. The consumers who have high price sensitivity may turn to Apple's competitors who offer lower prices. Furthermore, the competitive position of Apple is one of the internal strategic positions. First factor that can influence the competitive position is loyalty from customers. Apple has strong loyalty customers. Apple always invent products which meet the needs and demands of its consumers. The second factor that influences the competitive position is product quality. Apple has a consistent of good quality products which help to support the profit of Apple. The consistency of providing quality products has maintained the satisfaction of customers.

Lastly, the industry position of Apple in the external strategic positions has a great score. Apple has good potential in profitability. In 2019, the company increases 2 percent from the previous quarter and increases 4 percent in earnings per share (Apple.com, 2019). IPhone is the most profitable business line of Apple. Moreover, Apple is stable in finance. In order to have a strong finance, a company must have a strong equity ratio. In 2020, Apple generated $69.2 \%$ return of equity which is double of the average return of equity (finbox.com, 2020).

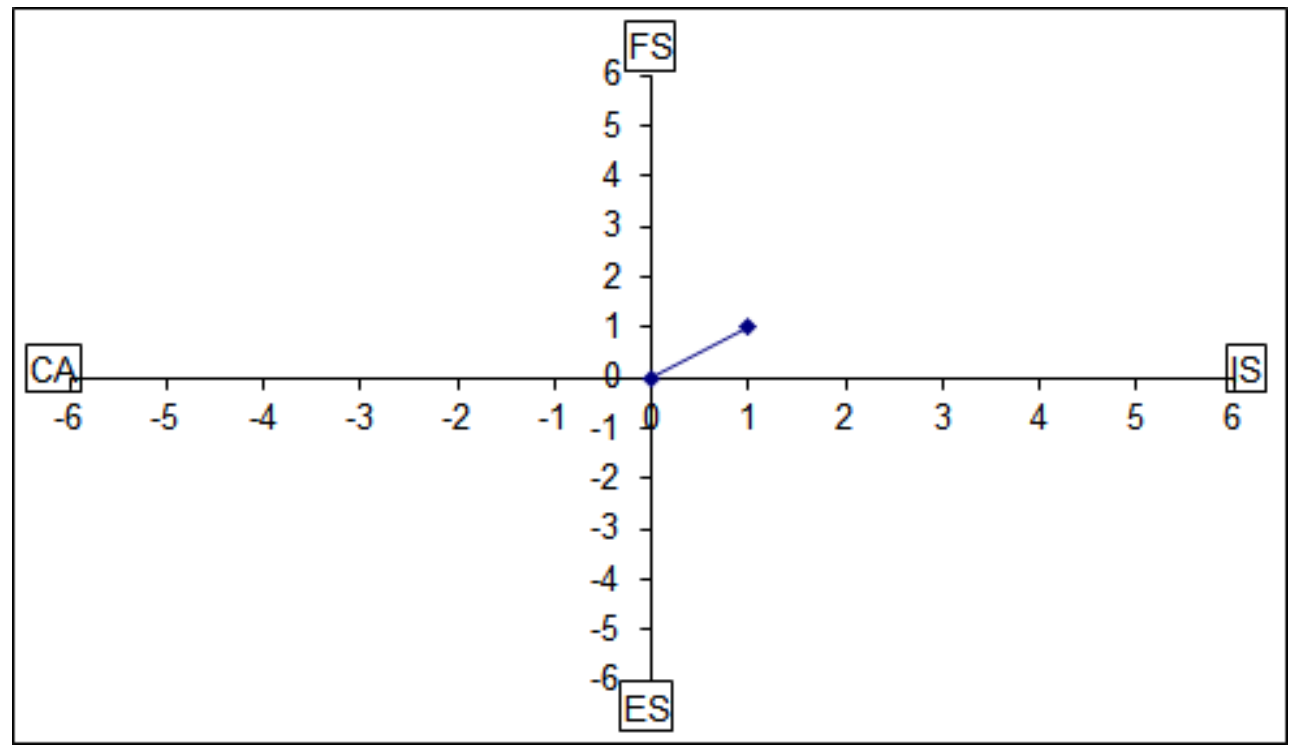

Figure 1 Space Matrix for Apple Inc.

According to the space matrix chart in Figure 1, it shows that Apple should pursue aggressive strategy. Apple should take into consideration actions that are suitable for the strategy. Apple has a directional vector coordinate of $(+1.00,+1.00)$. This has emphasized that Apple is having a strong competitive position and high growth in the market. In addition, Apple requires to make use of firm's internal strength to exploit market development and market penetration.

\section{Boston Consulting Group (BCG) Matrix}

BCG matrix is specifically designed to amplify a multidivisional organization's effort to develop strategies (Morrison and Wensley, 1991). There are several products from Apple that were being analyzed based on Figure 2. Firstly, cash cows are a market leader that produces more money than it depletes (Martin, 2020). In the cash cows quadrant (below left corner), position company's business units that give high revenue and require low investment in return to sustain profitability. Large companies such as Apple Inc. are capable of innovation and creativity. The product that is categorized is MacBook, which has successfully remained a firm position in this category for Apple. Secondly, stars usually engage in high growth industries and would remain a higher market share and expandable compared to their competitors (Bloom and Kotler, 2020). In the stars quadrant (top left corner), position the business units are highly potential for market growth where the company may plan to exploit with launching a new model. For instance, the iPhone is classified in this category. This happens whenever there is a new launch on their new version of iPhone, which will hit the new 
sales target. Thirdly, question marks, which are products that require Apple to consider whether they are worth investing in. They hold a low market share and consume large amounts of cash (Businesstoyou.com, 2017). In the question marks quadrant (top right corner), position the products are given potential to grow if issues are managed well. AppleTV is categorized in this category. Although AppleTV earns a small amount of profit, but it does not reach its true potential. Apple should solve their products ecosystem issues to own a space for TV. Lastly, dogs are products that were expected to have a high potential growth however failed to grow due to slow market growth. In the dogs quadrant (below right corner), explain that the business units need to be more cautious as the products may not yield any profit to the company. IPods are classified in this category, which were considered the best portable music player when they were released into the market. Yet, iPods failed to make a huge influence on society due to high competition of product and low demands from customers (Luenendonk, 2018).

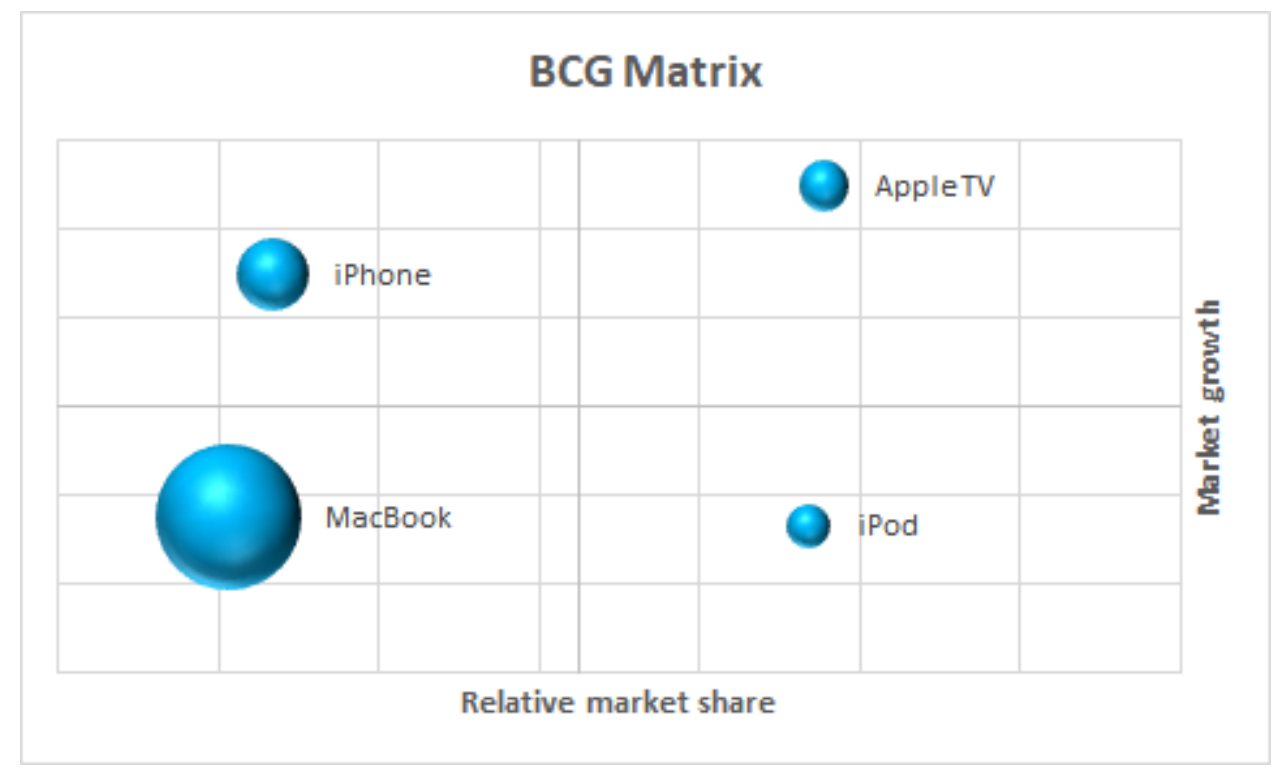

Figure 2 BCG Matrix for Apple Inc.

\section{Internal External Matrix}

IE Matrix is a tool to plot the organization division in a schematic diagram. The matrix plots Apple in nine different divisions. Each cell represents every division's percentage sales contribution (Utami and Ali, 2012). The matrix depends on the two dimensions which is the score of External Factor Evaluation in the $y$-axis and the score of Internal Factor Evaluation in the x-axis. Based on the two axis (Figure 3), IFE and EFE's total weight score of 1.00 to 1.99 represents a weak internal position while 2.00 to 2.99 shows average and a score of 3.0 to 4.0 indicates strong. The score of EFE for Apple is 4.0 whereas the score of IFE for Apple is 4.0. Cell I, II and IV are positioned as 'grow and build strategy', whereas cell III, VI and VII are strategy positions as 'hold and maintain' and the last cell of VI, VIII and VIV are considered 'harvest or divest' strategy. From the IE matrix above tells us that Apple is located at cell I which means the company should go for a growth and build strategy. Apple could implement strategies that are focused more on market development, product development and market penetration (Cassidy et al., 2013). Under market development, Apple can sell their current product in new market segmentation. Apple has expanded to 150 countries but there are more countries that Apple could expand (malaymail, 2020). For instance, Apple could sell their products in new markets like Africa and Indonesia. Second, for product development, means that Apple could produce new products in the current market. Apple is good at developing new products to meet the demands of customers. Apple starts its journey by inventing "Apple I" and continues inventing new products and services like Apple TV and App Store (Weinberger and Hartmans, 2020). Apple still continues to develop new products. Lastly, selling existing products in the markets to 
increase the share market of the company is consider as market penetration. For instance, Apple sells more iPhone to its existing markets. Apple can apply this strategy by available iPhone to be purchased on different platforms like Telecommunication Company, Apple stores and Apple website.

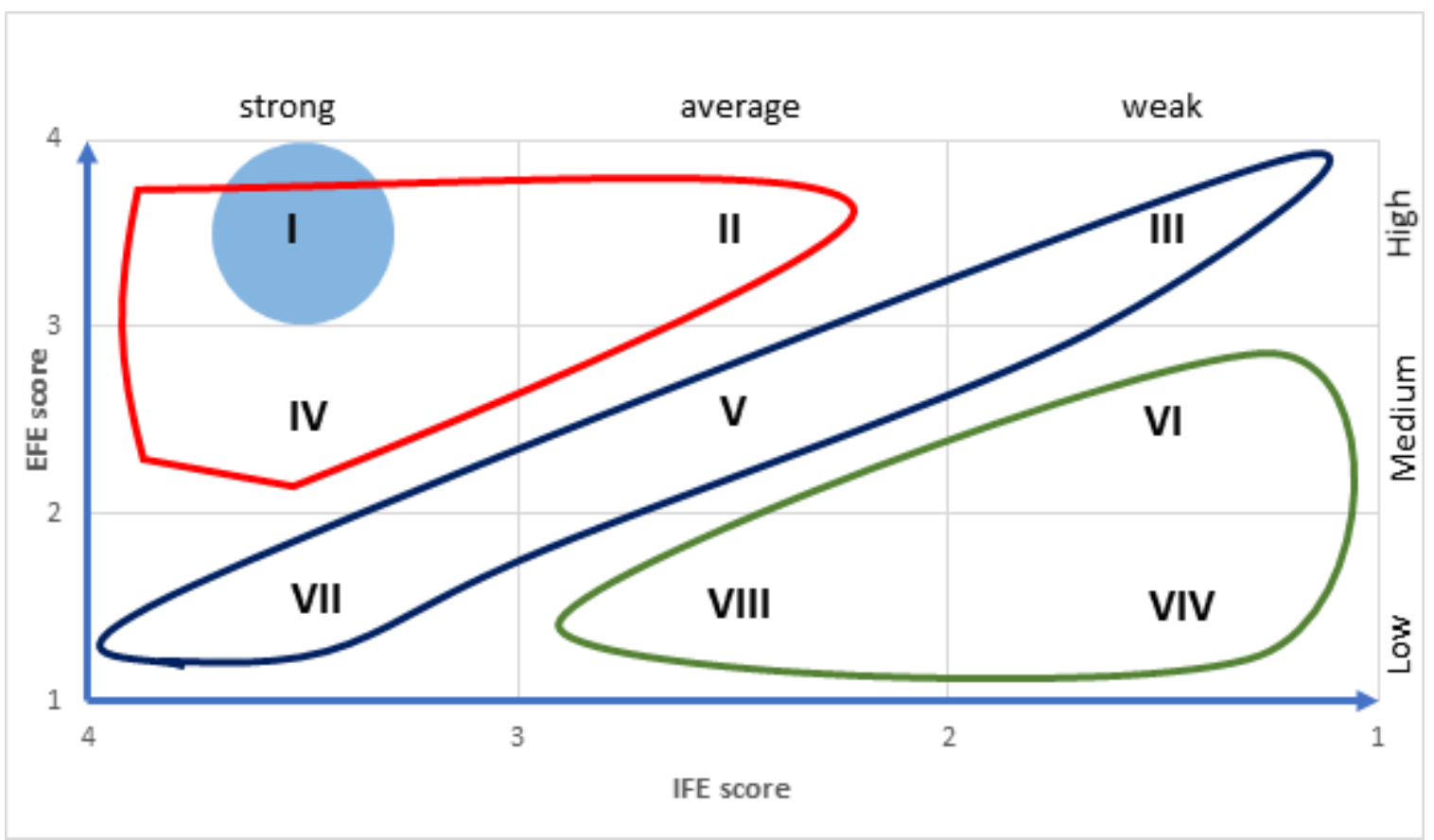

Figure 3 shows IE matrix for Apple Inc.

\section{Literature 'Art of War' By Sun Zi}

In Chinese literature, "Sun Zi Art of War" is the oldest military classic in China. The art of war strategy was written by Sun $\mathrm{Zi}$ is comprised of 13 chapters. Sun $\mathrm{Zi}$ as a military general has a great opinion on military strategy that he planned every movement that may affect the result of war (Combs, 2000). During that era, winning is his only goal and no lost battle. Ultimately, Sun Zi's strategy can be applied by Apple to defeat its competitors in order to gain market place in business.

\section{Waging War}

Based on chapter 2 of Art of War, the "Waging War" can be defined as "Going to War" and it means the economic nature of competition nowadays. In business terms, we can summarize how an organization achieves its success by limiting the conflict and cost of competition. As Sun Zi says, "In war, to win with one hundreds victories in one hundred battles is not the prime of skills. In the opposite, to subdue the opponent without fighting is known as the acme of skills." The theory tells why Sun Zi teaches about the importance of 'winning without conflict' where competition with others is considered expensive. Although winning in a battle and beating an enemy may satisfy the ego, however it is considered as a foolish way in reaching the goal (Wee, 2002). Another theory learned by $\mathrm{Sun} \mathrm{Zi}$ is, "in order the troops to pillage enemy's resources, they should be motivated by giving material rewards." Sun $\mathrm{Zi}$ explained that the soldier who captured ten enemies will be rewarded. Then, the captured soldiers should be treated well and used by ours so that the battle could be won easily (Chu and Tse, 1992).

In a business environment, employees are the most essential asset in the organization where they do the task to keep the business going. Therefore, every success company should recognize their contribution by rewarding them. In this case, Apple implemented this theory in the organization. Apple Company utilizes intrinsic and extrinsic rewards to motivate its employees. According to UK's Employee Benefit (2019), Apple rewarded a 5\% recognition bonus of salary to its employees who have achieved the goals given by the company. Throughout this motivation method, Apple's 
employees with job satisfaction could complete their work effectively. Another reward can be given to employees is the first to receive Apple's latest IPhone model as a gift. This could not only be a benefit for the good performance employees but also an effective way for employees to increase their productivity as well as learning the experience from the new product. For instance, Tim Cook, CEO of Apple also did the same strategy where he sent out a memo by thanking whole Apple's employees for their contribution in helping the company. He gave extra holiday for his employees by extending the Thanksgiving holiday. Apple's employees who gained this material reward feel satisfied and push them to be even better next year (Yarow, 2012).

\section{Attack by Stratagem}

Based on the chapter 3 of Art of War, "Attack by Stratagem" can be defined as "Strategic Attack" and it means that the measurement of a standard strategy to win in a battle field. In business terms, we can summarize that a business strategy is an important factor for an organization in this competition industry. As Sun $\mathrm{Zi}$ says, "attacking the plan of the enemy is the most incredible strategy". The theory explains why Sun Zi believes in making sure the enemy surrenders in fighting war is the first option, whereas winning the war with physical force is the second option. The theory also had another meaning that the strength source is defined as one unity and is not equal for everyone. In order to win over the enemy, we should plan about the strategies beforehand to perfectly win the war (Allen, 2015). Another theory learned by Sun $\mathrm{Zi}$ is, "if we know ourselves and know the enemies will have a higher chance of victory". Sun $\mathrm{Zi}$ explained that if you are lacking enemy info but understand more about yourself, the chances of losing or winning will be equal. However, if you don't understand the other side and yourself, you are sure to be bound to be defeated in every war (Fernandez, 2004).

In this era of globalization, understanding strategy from competitors could lead an organization to have a greater planning and become a successful company in the international market (Allen, 2015; Islam, 2015; Leswing, 2019). Moreover, the organization will also face problems if they get the wrong information from competitors. In this case, Sun Zi's theory is applied in Apple's business strategies. In business nowadays, there are numerous large companies producing smartphones around the globe. However, Apple applied this theory to attack the strategies of rivals and gain success in the international market. In 2016, Apple became the largest smartphone vendor and captured $18 \%$ of the world market share (Statista, 2020). Apple implemented this theory by using iOS software as a strategy to attack its enemy. This newest advanced mobile operating system is better than the Android version where it provides stronger security for iPhone users. Another strategy for Apple to utilize for attacking enemies is focusing on Apple's product design and integration. Customers that bought Apple's product had difficulties switching to another brand as it will not be compatible with other devices (Leswing, 2019). In the end, the principle to win the competition is to have your own well-planned strategies. Apple should understand its own strength and focus on the enemy's strategy in order to win the war.

\section{Use of Energy}

Based on chapter 5 of Art of War, "Use of Energy" can be defined as "Forces" and it means the fighting process included two forces which are indirect and direct strategies. Related with the real world business strategies, we can summarize that an organization needs to be well-prepared before a company enters competition. The organization should include resources such as knowledge, skills, manpower and many more. As Sun Zi says, "in order to win over another enemy, the company should use indirect forces to win the enemy and use direct force to match them". The theory explains Sun $\mathrm{Zi}$ believes the impact of combinations of two force types are infinite and its interactions will bring great results. The theory also explains that the two forces interactions are like two never-ending interlocks where the beginning and ending possibilities could not be determined (Hawkins and Rajagopal, 2004). Another theory learned by Sun $\mathrm{Zi}$ is, "in order to stimulate the weakness before any enemy, that person needs to have a dominance of forces". Sun $\mathrm{Zi}$ explains that indirect forces 
are also known as differentiation, where the strategy could be utilized to reduce sensitivity of its provision features to outperform rival brands in the business area (Michaelson, 2003).

As mentioned by Sun $\mathrm{Zi}$, this theory is to come out with a strategy that provides a product or service that is differentiated from its competitors. If fail, the development of the organization may spurn. In this case, Apple practiced this theory into its business strategy where the organization utilized differentiation strategy by introducing unique design and features of product development in order to enter the market. Apple blends Sun Zi theory into its business aspect to gain a large segment of potential customers as well as enhancing its market position. Apple creates software and hardware that is exclusively only available for Apple products. One of the business strategies that Apple applied to achieve competitive advantage is innovation. Apple perceives the uniqueness of its product by emphasizing the usage of apps and touch-screen into smartphones (Hern, 2018). In order to fight its enemy, the organization came out with a handful of ways to improve its weakness and make use of all its strength to capture more market profit.

\section{Conclusion}

To conclude, the most interesting about Apple is how the company became very innovative. In a long-term growth, Apple will stay on to enjoy the accessible opportunities. Nevertheless, it will be beneficial for Apple to upgrade some of its approach in order to effectively address challenges may encountered in the future. The reason behind its assured success is Apple has an ability of adapting to the challenging environment. Its distinct features such as unique design could be the competitive advantage, which brought the company rise in revenues. Hence, it is appropriate to state that Apple can prosper to become a leader in the electronics industry.

\section{References}

Ahmer, A. (2019). A Brief History of Apple Inc. Doersempire. Available at: https://www.doersempire.com/a-brief-history-of-apple-inc/ [Accessed 6 Oct. 2020].

Aljafari, A. (2016). Apple Inc. Industry Analysis Business Policy and Strategy. International Journal of Scientific \& Engineering Research, 7(3), 406-408.

Allen, B. (2015). War as a Problem of Knowledge: Theory of Knowledge in China's Military Philosophy. Philosophy East and West, 65(1), 1-17.

AllianceExperts.com, (2020). International Distribution Strategy and Marketing Channels. Available at: https://www.allianceexperts.com/en/knowledge/exports/internationaldistribution-strategy/ [Accessed 6 Oct. 2020].

Appel, G., Grewal, L., Hadi, R. and Stephan, A. T. (2019). The Future of Social Media in Marketing. Journal of Academy of Marketing Science, 48(1), 79-95.

Apple.com, (2000). Media Alert. Apple. Available at: https://www.apple.com/newsroom/2000/04/14Media-Alert/ [Accessed 29 Sept. 2020].

Apple.com, (2020). Apple reports Third Quarter Results. Apple. Available at: apple.com/newsroom/pdfs/FY20-Q3_Consolidated_Financial_Statements.pdf [Accessed 7 Oct. 2020].

Apple.com, (2020). Genius Bar Reservation and Apple Support Options. Apple. Available at: https://www.apple.com/retail/geniusbar/ [Accessed 6 Oct. 2020].

Apple.com, (2020). Guidelines for using Apple Trademarks and Copyrights. Available at: https://www.apple.com/legal/intellectual-property/guidelinesfor3rdparties.html [Accessed 6 Oct. 2020].

Apple.com. (2019). Addressing Spotify's Claim. Apple. Available at: https://www.apple.com/newsroom/2019/03/addressing-spotifys-claims/ [Accessed 6 Oct. 2020].

Apple.com. (2019). Apple Reports Fourth Quarter Results. Apple. Available at: https://www.apple.com/newsroom/2019/10/apple-reports-fourth-quarter- 
results/\#: :text=Cupertino\%2C\%20California\%20\%E2\%80\%94\%20October\%2030\%2C,o f\% 20\%243.03\%2C\%20up\%204\%20percent. [Accessed 14 Oct. 2020].

Apple.com. (2020). Apple Services now available in more countries around the world. Apple Newsroom. Available at: https://www.apple.com/newsroom/2020/04/apple-services-nowavailable-in-more-countries-around-the-world/[Accessed 5 Oct. 2020].

Blodget, H. (2013). Apple's 'Mission Statement' is Making People Worry That The Company Has Gone To Hell. Business Insider. Available at: businessinsider.com/apples-new-missionstatement-2013-8 [Accessed 29 Sept. 2020].

Bloom, P. and Kotler, P. (2020). Strategies for High-Market Share Companies. Harvard Business Review. Available at: https://hbr.org/1975/11/strategies-for-high-market-share-companies [Accessed 6 Oct. 2020].

Businesstoyou.com. (2017). BCG Matrix: Portfolio Analysis in Corporate Strategy. B2U. Available at: https://www.business-to-you.com/bcg-matrix/ [Accessed 7 Oct. 2020].

Cassidy, C. M., Glissmeyer, M. D., and Capps III, C. J. (2013). Mapping an Internal-External (IE) Matrix using Traditional and Extended Matrix Concepts. Journal of Applied Business Research (JABR), 29(5), 1523-1528.

Castro, A. How Apple Makes Billions of Dollars Selling Services? The Verge. Available at: https://www.theverge.com/2019/3/20/18273179/apple-icloud-itunes-app-store-musicservices-businesses [Accessed 6 Oct. 2020].

Chu, P. and Tse, O. (1992). The Art of War and Strategic Management. Journal of Management Education, 16(4), 43-53.

CNN Business, (2006). Apple Inc. CNN. Available at: https://money.cnn.com/quote/shareholders/shareholders.html?symb=AAPL\&subView=inst itutional [Accessed 6 Oct. 2020].

Combs, S. C. (2000). Sun-zi and The Art of War: The Rhetoric of Parsimony. Quarterly Journal of Speech, 86(3), 276-294.

Csimarket.com. (2020). AAPL's Revenue Growth by Quarter and Year. CSIMarket. Available at: https://csimarket.com/stocks/single_growth_rates.php?code=AAPL\&rev [Accessed 6 Oct. 2020].

David, F. R. (2011). Strategic Management: Concepts and Cases, Prentice Hall: New Jersey 13th ed, 80 (122), 177-179.

David, M. E., David, F. R., and David, F. R. (2017). The Quantitative Strategic Planning Aatrix: A New Marketing Tool. Journal of Strategic Marketing, 25(4), 342-352.

EmployeeBenefits.co.uk, (2019). Employee Rewards: Who Would you Rather Work For - Amazon or Apple? Employee Benefits. Available at: https://employeebenefits.co.uk/employeerewards-who-would-you-rather-work-for-amazon-or-apple/ [Accessed 7 Oct. 2020].

Farfan, B. (2019). Apple's Retail Stores around the World. The Balance SMB. Available at: https://www.thebalancesmb.com/apple-retail-stores-global-locations-2892925 [Accessed 6 Oct. 2020].

Fernandez, J. A. (2004). Management in Times of Change: Lessons from the 'Art of War'. Business Strategy Review, 15, 51-58.

Finbox.com. (2020). Return on Common Equity for Apple Inc. [Online]. Finbox. Available at: https://finbox.com/NASDAQGS:AAPL/explorer/roe\#: :text=Apple's\%20operated\%20at\% 20median\%20return,in\%20September\%202017\%20of\%2036.9\%25. [Accessed 14 Oct. 2020].

Forexfactory.com (2020). Apple Revenue up $11 \%$ and EPS up $18 \%$ to new June quarter records. Forex Factory Available at: https://www.forexfactory.com/news/1016422-apple-revenueup-11-and-eps-up-1 [Accessed 7 Oct. 2020].

Guo, L., Hsu, S. H., Holton, A. and Jeong, S. H. (2012). A Case Study of Foxconn Suicides: An International Perspective to framing the Sweatshop Issue. International Communication Gazette, 74(5), 484-503. 
Haselton, T. (2017). Here's why people keep buying Apple products. CNBC.com. Available at: https://www.cnbc.com/2017/05/01/why-people-keep-buying-apple-products.html [Accessed 30 Sept. 2020].

Hawkins, D. E., \& Rajagopal, S. (2004). Sun Tzu and the Project Battleground: Creating Project Strategy from 'the Art of War'. Springer.

Heffernan, M. (2013). What happened after the Foxconn suicides. CBSNews. Available at: https://www.cbsnews.com/news/what-happened-after-the-foxconn-suicides/ [Accessed 30 Sept. 2020].

Hern, A. (2018). From Macs to iPods and apps: how Apple revolutionised technology. The Guardian - Tech. Available at: https://www.theguardian.com/technology/2018/aug/02/macs-ipodsapps-how-apple-revolutionised-technology [Accessible at 7 Oct. 2020]

Islam, M. A (2015) Globalization creates 'Global Village' For Businesses: Main Considerations and Challenges. Bangladesh Research Publications Journal, 11(1), 93-99.

Johnson, K., Li Y., Phan H., Singer, J. and Trinh, H. (2012). The Innovative Success that is Apple, Inc. Theses, Dissertations and Capstones, 418(1)

Johnson, K., Li Y., Phan H., Singer, J. and Trinh, H. (2012). The Innovative Success that is Apple, Inc. Theses, Dissertations and Capstones, 418(1)

Khan, U. A., Alam, M. N., \& Alam, S. (2015). A critical analysis of internal and external environment of Apple Inc. International Journal of Economics, Commerce and Management, 3(6), 955961.

Leswing, K. (2019). The iPhone decade: How Apple's phone created and destroyed industries and changed the world. CNBC News - TECH. Available at: https://www.cnbc.com/2019/12/16/apples-iphone-created-industries-and-changed-theworld-this-decade.html [Accessible at 7 Oct. 2020]

Luenendonk, M. (2018). The Apple Product Strategy. Cleverism. Available at: https://www.cleverism.com/apple-product-strategy/ [Accessed 7 Oct. 2020].

Malaymail.com. (2020). Apple App Store to expand to 20 more countries. Malay Mail - Tech. Available at: https://www.malaymail.com/news/tech-gadgets/2020/03/25/apple-app-storeto-expand-to-20-more-countries/1849998 [Accessed 6 Oct. 2020].

Manjoo, F. (2016). What's Really Missing From the New iPhone: Cutting-Edge Design. The New York Times - Technology. Available at: https://www.nytimes.com/2016/09/08/technology/whats-really-missing-from-the-newiphone-dazzle.html[Accessed 5 Oct. 2020].

Martin, M. (2020). What is a BCG Matrix? Business News Daily. Available at: https://www.businessnewsdaily.com/5693-bcg-matrix.html [Accessed 6 Oct. 2020].

Mastroianni, B. (2016). Apple launches Twitter account for Customer Service. CBS News. Available at: https://www.cbsnews.com/news/apple-launches-twitter-account-for-customer-service/ [Accessed 29 Sept. 2020].

Michaelson, G. A., \& Michaelson, S. W. (2003). Sun Tzu for success: How to use the art of war to master challenges and accomplish the important goals in your life. Simon and Schuster.

Montgomerie J. and Roscoe, S. (2013). Owning the Consumer - Getting to the core of the Apple Business Model. Accounting Forum, 37(4), 290-299.

Moorman, C. (2012). Why Apple Is a Great Marketer. Forbes. Available at: https://www.forbes.com/sites/christinemoorman/2012/07/10/why-apple-is-a-greatmarketer/\#c7ceea8297d2[Accessed 5 Oct. 2020].

Morrison, A., \& Wensley, R. (1991). Boxing up or boxed in?: A short history of the Boston Consulting Group share/growth matrix. Journal of Marketing Management, 7(2), 105-129.

Nellis, S. (2020). Apple Expands Services Business to Markets in Africa and Beyond. Reuters. Available at: https://www.reuters.com/article/us-apple-services-idUSKBN2230R8 [Accessed 5 Oct. 2020]. 
Nielsen, S. (2020). Apple's Premium Pricing Strategy, Product Differentiation. Market Realist. Available at: https://marketrealist.com/2014/02/apples-premium-pricing-strategy-productdifferentiation/ [Accessed 6 Oct. 2020].

Phadermrod, B., Crowder, R. M., and Wills, G. B. (2019). Importance-Performance Analysis based SWOT Analysis. International Journal of Information Management, 44(1), 194-203.

Shanklin, W. (2017). Samsung Notebook 9 vs. Apple Macbook Pro (13-inch). New Atlas. Available at: $\quad$ https://newatlas.com/macbook-pro-vs-samsung-notebook-9-comparison/47383/ [Accessed 6 Oct. 2020].

Sheda. (2016). How to: Business Model Canvas Explained. Medium.com. Available at: https://medium.com/seed-digital/how-to-business-model-canvas-explained-ad3676b6fe4a [Accessed 6 Oct. 2020].

Statista.com. (2020). Global smartphone market share from 4th quarter 2009 to 2nd quarter 2020. Statista. Available at: https://www.statista.com/statistics/271496/global-market-share-heldby-smartphone-vendors-since-4th-quarter-2009/ [Accessible at 7 Oct. 2020]

Swant, M. (2020). The 2020 World's Most Valuable Brands. Forbes. Available at: https://www.forbes.com/the-worlds-most-valuable-brands/\#300a8468119c [Accessed 30 Sept. 2020].

Utami, E. and Ali, I. (2012). Formulation of Company Strategy Based on Competitive Advantage, $11(2), 154-164$.

Valentin, E. K. (2001). SWOT Analysis from A Resource-Based View. Journal of Marketing Theory and Practice, 9(2), 54-69.

Wall, S. (2018). What does Apple Inc's (NASDAQ:AAPL) Ownership Structure look like? Simply Wall. Available at: https://simplywall.st/stocks/us/tech/nasdaq-aapl/apple/news/what-doesapple-incs-nasdaqaapl-ownership-structure-look-like/ [Accessed 6 Oct. 2020].

Wee, C. H. (2002). Sun Zi Art of War and SWOT Analysis: Perspectives and Applications to Business. Asia Pacific Management Review, 7(2), 267-286.

Weinberger, M. \& Hartmans, A. (2020). Apple just became a \$2 trillion company. Here's how it came to rule the world, from its early struggles to beat Microsoft to the launch of the iPhone. Business Insider. Available at: https://www.businessinsider.com/history-of-apple-in-photos2015-8 [Accessed 6 Oct. 2020].

Wonglimpiyarat, J. (2012). Technology Strategies and Standard Competition-Comparative Innovation Cases of Apple and Microsoft. The Journal of High Technology Management Research, 23(2), 90-102.

Yarow, J. (2012). Tim Cook is giving Apple Employees an Extended Thanksgiving Break. Business Insider. Available at: https://www.businessinsider.com/tim-cook-letter-2012-10 [Accessed 7 Oct. 2020]. 